\title{
SUBLIMATION AS A PARADIGM OF THE PSYCHE CONSTITUTION: METAPSYCHOLOGY AND THEORETICAL-CLINICAL DEVELOPMENTS*
}

Leandro Anselmo Todesqui Tavares and Francisco Hashimoto

Leandro Anselmo

Todesqui Tavares

Faculdade

Integradas de

Ourinhos (FIO),

Departamento

de Psicologia,

Ourinhos - SP,

Brasil.

Faculdade da Alta

Paulista (FAP),

Departamento de

Psicologia, Tupã/SP,

Brasil.

Francisco Hashimoto Universidade Estadual Paulista (UNESP), Faculdade de Ciências e Letras, Assis/SP, Brasil.

\begin{abstract}
The present study aims at understanding sublimation as a psychicevent inextricablylinked to theadvent of the subject, being then characterized as a singular and paradigmatic subjectivation process in what regards the psychic constitution. We begin with a brief theoretical-conceptual review with respect to Freud's process of sublimation, as well as the return and deepening carried out by Lacan, and considering contemporary articulations on the subject, we relate its importance, long neglected, with regard to the aspects and theoretical-clinical developments, as well as its fundamental importance with respect to understanding the psychic constitution within the psychoanalytic framework.
\end{abstract}

Keywords: Sublimation; Psychoanalysis; Creative Processes.

RESUMO: A sublimação como paradigma da constituição psíquica: metapsicologia e desdobramentos teórico-clínicos. O presente estudo presta-se a uma compreensão da sublimação como um evento psíquico inextricavelmente atrelado ao advento do sujeito, caracterizando-seassim como um processo de subjetivação singular e paradigmático no que se refere à constituição psíquica. Iniciamos com uma breve revisão teórico-conceitual com relação ao processo sublimatório em Freud, bem como sua retomada eaprofundamento efetuadosporJ.Lacan,econsiderandoarticulações contemporâneas sobre a temática relacionamos sua importância, há muito tempo negligenciada, no que se refere aos aspectos e desdobramentos teórico-clínicos, bem como sua fundamental importância no que diz respeito à compreensão da constituição psíquica dentro do referencial psicanalítico.

Palavras-chave: Sublimação; Psicanálise; Processos Criativos.

DOI - http://dx.doi.org/10.1590/S1516-14982016002010 
$\mathrm{T}$ o think and to articulate the concept of sublimation in Psychoanalysis is not a simple thing, so such task puts the psychoanalytic researcher directly in contact with text fragments in which Freud showed, throughout his work, even if indirectly, an ever-growing concern in defining such conceptualization. When revisiting Freud's path with respect to this issue, it is evident that if at first we could find slight references to the concept of sublimation as an explanatory resource to other conceptual apparatus, later and in other studies, his concern regarding this problematic returns, featuring then a need of understanding and research about sublimation as one of the most thought-provoking questions for Psychoanalysis.

In this way, we intend at first to make the evolution of the concept of sublimation more clear considering such reformulations and breakthroughs from Freud to Jaques Lacan, from sublimation as a possible drive destiny (Freud 1915/1996) to the consistency of the "final product" as an object elevated to the dignity of the Thing (LACAN, 1959-60/2008). In addition, a closer study of the sublimation process enables us to reflect on the limits of an analysis, emphasized by Freud, and resumed by Lacan. Thus, the theoretical-clinical developments about sublimation, including its metapsychologic aspects, appear to be invaluable in what refers to the creations of possibilities before the repetition compulsion, before what appears as an obstacle and a limit to the interpretative method.

We note at first, that a discussion about sublimation causes, above all, understandings that involve the creative processes that were thought from the theoretical framework of Psychoanalysis. It's important then to recall that from the beginning, the psychoanalytic method itself (free association) is characterized by the analyst as a bet in the creative power of the subject that undertakes a speech. However, except for other applications of the psychoanalytic technique, the fact is that we will always find in the field of the culture, some possibilities for the subject to constitute and produce destinations, according to his desire, using his intersubjective relations and the alterity social bonds formed from this point. Thus, from this perspective of openness with regard to a discursive proliferation requested by the patient, we can understand that this is also fundamentally, for beyond the possibility of a psychic elaboration with regard to conflicts, an invocation of the creative capacity of the subject: here's why, and the relevance of sublimation for Psychoanalysis.

\section{FREUDIAN OUTLINES}

When we reconstitute the Freudian path with respect to this theme, we can identify two major conceptions about the sublimation process: one that Freud considers as being a psychic activity in which a desexualization of the drives would 
be involved (recognition/social valorization). Then, another conception becomes meaningful from the preparation of the second topical, from where it was possible to understand sublimation as implying a change of target/objective of the drive, which takes Freud to consider the sublimation process as one of the possible destinations of the drive.

In "Civilized Sexual Morality and Modern Nervous Illness" of 1908, Freud develops a line of reasoning in which he identifies as a base and motor of the highest human achievements a force originated from what would be the lowest and most threatening social/collective point of view, which in the words of Birman (2002) would characterize it as the most abject in the human being, that is, the perverse-polymorphous sexuality. Let us remember that, according to Freud, the existence of culture as well as the possibility of survival in the collective implies the subject an instinct waiver, so that in erotic terms the only admitted sexuality would be that of the genital sexuality, i.e., the one directly related to the forces of Eros and to the propagation of the species.

In this respect, the final result of the processes of sublimation during Freud's time as a direct correlate of a form of social regulation in nothing differs from the defense mechanism of repression, and in this way, according to Birman (2002), rather than the man's "spiritual uplift", the fate of such desexualizations would be just the final installation of the "discontent" in culture (Freud, 1930[1929]/1996).

Another relevant issue still stands within this first conception, in so far as it implicitly to this modality of conceptual definition that we can envision that, on the horizon of what psychoanalysis could understand as being a step forward on the path to "cure" (still in the first Freudian topical) a paradox is stressed, to the extent that here such cure would be a synonym of instinct resignation. Paradoxical, as Castiel (2007, p. 38) points out: "what would be the meaning of the analytical process if in front of the truth of his desire, the subject would be placed in opposition to pleasure and thus would have to give it up because of a moral question?". Anyway these are theoretical issues with practical implications that this first conceptual definition of Freud couldn't solve.

In 1910 we can already identify new important considerations in the essay "Leonardo da Vinci and a Memory of His Childhood", or else radical, even in this second moment about sublimation. In theoretical and conceptual terms, Freud's turning point initiated in this text, and complemented elsewhere in his work, points to a break in his initial formulation on sublimation characterized in 1908. From this study on the life and work of Leonardo da Vinci, Freud formulates the process of sublimation as not belonging to the desexualization of the drives, on the contrary, he directly finds in Leonardo's productions the evidence of the strong presence of sexuality, so then he begins to understand the sexual drive as a force that gives rise to sublimation. In this case, Freud wonders about the existence 
of a knowledge drive, which is evidenced by Leonardo's scientific curiosity, assuming then that such drive would be formed from the children's sexual curiosity, however, considering that such children's sexual curiosities from its inception would be sublimated featuring another destination other than the discharge of such drive forces.

In short, we can find in Freud, from this moment, a new understanding about sublimation, because, although the change of the drive objectives implies necessarily also in the object change, the fact is that on the one hand a partial drive satisfaction is characterized, also observing that sexuality itself (perversepolymorphous) subsists in such productions. Anyway, new understandings about the goal and about the object in the problem of sublimation would then be formulated, which from then on shows us that the process of sublimation concerns a subject's functioning on another psychic level and not just a mere construction/production of a socially valuable object.

In 1914 in the text "On narcissism: an introduction" and later in "Instincts and their vicissitudes" (1915), we observe Freud's movement in the attempt of reformulating some concepts where the keynote leans more towards an issue related to the libido and the drives than just only to an unconscious capable of storing repressed contents. This text about narcissism (1914) condenses a multiplicity of information and that's why it is considered a landmark of the rupture in Freud's theory. And in relation to the process of sublimation it is evident in this period that Freud is concerned with the problem of the so-called ego-libido and objectlibido, so that we can already understand here an upcoming need for a definition about something that a year later Freud would define as being related to the drive. That is, being the ego-libido the term which refers to the psychic process of the libidinal investment over the ego itself, and the object-libido featuring the libidinal investment in objects (external to the ego), the evidenced issue refers to a dynamic circuit of investment. In this text Freud even questions whether the withdrawal of the object-libid o for the ego could not characterize the universal path of all sublimation; however, in the following year such issues will get other considerations from the concept of drive.

In 1915 in the text "Instincts and their vicissitudes" Freud is dedicated exclusively to the definition of that concept. This text will be complemented later in 1920 when he writes "Beyond the pleasure principle", since at this moment (1915) Freud still works with the thesis that the instincts (that is, drive) would share in ego instincts (self-preservation) and sexual instincts. It is at this moment that Freud articulates what would then be the peculiar characteristics of the drives, which are: the drive as a constant force acting on the psyche, that is, its pressure (Drang); The purpose (Ziel) of the instinct which always aims satisfaction; The object (Objekt) being the thing by which an instinct is able to satisfy itself. And finally, 
the source (Quelle) of the drive located within the body itself. Among these features explained by Freud, its development with respect to the issue of the purpose and of the object of the drive (given its "flexible" character) opens the way to articulate sublimation as one of the possible destinations of the drive. About this feature Freud says:

They are distinguished for having in wide measure the ability to act vicariously after each other, and for being able to move objects promptly. As a result of these last properties, they are capable of functions that are far from their original intentional actions — that is, capable of sublimation. (FREUD, 1915/1996, p. 131).

So, in this text, Freud formulates the possible destinations of the drives: the reversal into its opposite; the turning towards the self of the individual; the repression, and finally, the sublimation. It's necessary to recall here that Freud considers the first three vicissitudes as defense arrangements with respect to the drive emergency. This directly characterizes sublimation as a distinct psychic operation definitely belonging to the mechanism of repression. From then on it's possible to understand sublimation as a possible way out to the problem which is eminently economic (pleasure-displeasure), since the other vicissitudes considered by Freud are something concerning the conflict for the subject. If we can consider something related to a transformation regarding the purpose and the drive objects, maybe the concept of sublimation, among countless ones in psychoanalytic theory, is the one that best points to such understanding. Thus, sublimation, in the words of Nasio (1995, p. 88), would be exactly "the plastic drive capacity to change an object and to find new satisfactions".

Being the full satisfaction of the drive categorized in the order of the impossible, it suffers a discharge that is not direct, it suffers vicissitudes, by structural impossibility of the psyche, as the absolute jouissance is blocked to the subject and, if it were possible, would result in its death due to the drive excess which is unassimilable by the psyche.. Sublimation seems then to appear also as a means of protection against absolute jouissance, but it assumes psychic satisfactions for a vicissitude that escapes the repression and that differs from the defense mechanisms, where there is formation of commitment via formation of symptoms. In this way, the vicissitude of sublimation conveyed from the constitution and connection of the ego with another object will feature other possible satisfactions and distinct from the original requirements. 


\section{SUBLIMATION AND DEATH DRIVE}

The text that definitively marks Freud's turning point featuring perhaps the greatest conceptual disruption of the whole evolution of Freud's work is the well-known "Beyond the pleasure principle" of 1920. Here Freud explicitly formulates in conceptual terms the metapsychological resolution about the issue of drives which had already been raised in previous years through direct and indirect articulations present in other texts, as mentioned earlier. The breakthrough featured through the concept of death drive will still have direct implications on the understanding of the problem of sadism and masochism, in addition to the considerations with respect to melancholy. However, it is important to understand that this text of 1920 leads to understandings from which its triggering events are, in several of Freud's previous works, from its earliest formulations about the understanding of the drives (as a psychic requirement), passing by the new concepts from the preparation of the psychic instances, Id, Ego and Superego, as well as when Freud deals with the problems of ego-libido and object-libido among other theoretical constructs that present in these productions, even though between the lines and implicitly, a dissatisfaction with respect to the economic and dynamic problem in psyche:

It seems to have been primarily the theoretical value of the concept and its agreement with a certain conception of the drive that made Freud so worried in supporting the thesis of death drive, despite the "resistances" he came across in the psychoanalysis environment and in spite of the difficulties in basing it on concrete experience. (LAPLANCHE; PONTALIS, 2001, p. 409).

The Freudian metapsychology from such text is marked definitely by the rupture and at the same time by the opening of new horizons about the psyche raised by the formulation of the concept of death drive.

As Freud tells us at this moment, the life drive expresses a tendency of the psyche in adding, multiplying, unifying, constructing objects and materialities, whereas the death drive would aim at the breakdown and destruction of the units. While the life drive is necessarily articulated to the field of representation, the death drive, in turn, would not be subject to representation in the psyche, implying an issue characterized by a satisfaction requirement imposed on the psychic apparatus that is not able to be captured by a symbolic structure.

Another important characteristic that assists Freud in the corroboration of his thesis about the existence of the death drive is due to his observation and perception of the repetition that this implies. The repetition compulsion is an issue that is taken up with special interest by Freud in "Analysis terminable and interminable (19371996)" where this is understood as being one of the insurmountable limits 
to the therapeutic ranges of an analysis. Freud considers repetition as something related to the demonic, which is characterized by its compulsive aspect and being far beyond all possible assimilation on the part of the subject. Summarizing, further than any signified articulation that could result in new productions of the meaning, insights and psychic elaborations if we want to think specifically in some of the goals of an analysis regarding the psychic conflict.

To think about the constitution of the psyche from the introduction of the concept of death drive within the psychoanalytic theory puts Freud directly involved in the new technical issues, in what we could consider as being his concern with respect to the direction of the "cure". That is, still in the first theoretical productions developed by Freud, the question of therapeutics in its topic and dynamic levels are emphasized as the method of interpretation is favored. From the elaboration of the concept of death drive in 1920, followed by its implications of clinical order on what is expected of an analysis process and the obstacles mentioned by Freud in texts as the one from 1937, new psychoanalytical issues are shaped, in a highly economic record in what concerns the understanding of the psyche.Generallyspeaking, the clinical boundaries become apparent and irrefutable as an univocal bet towards the range of the method of interpretation, as far as the death drive, as the drive for excellence, indicates to the (ex)-istence of a rest in the psyche that is beyond the symbolic order. It is from this type of understanding that, in the words of Rinaldi (1996, p. 119): "For Freud, the unconscious is also something not-born, not accomplished, and, in this sense, unknowable."

Something which you cannot establish a direct knowledge, in itself, but rather, only through the creation of other objects representing it. Other objects that can represent it and not those that already represent it, therefore, already included in the symbolic order, even if they are under the forces of repression.

Complementing his new theoretical articulations and the resulting problems, Freud in "New introductory lectures on psychoanalysis" (1933/1996) emphasizes once again the role of death drive in the psychic constitution, as well as in the formation of social ties. Clinically, death drive is directly associated with the unconscious feeling of guilt, so Freud, although having approached this theme in "Civilization and its discontent" (1930/1996), now reinforces the idea that the high cost required to men in the name of civilization, more than to the repression of sexuality, is due to repression against the aggressive instincts (death drive). However, it is up to us to reflect and consider that a careful reading in relation to Freud's considerations on this issue does not take us to a necessarily pessimistic understanding with respect to human suffering. After all, Freud in this text asserts that in one way or the other, drives are always condensed to each other, which makes us understand the continuous interlacing between life and death: 
We're not claiming that death is the only aim of life; we are not overlooking the fact that there is life as well as death. We recognize two basic instincts, and give each of them its own aim. As the two mingle in the processes of life, as the death drive is at the service of the purposes of Eros, especially being backed out in the form of aggressiveness - these are tasks reserved for future research. We didn't go beyond the point where this approach is open to us. (FREUD, 1933/1996, p. 109).

And in his last words regarding the drives in this text about anxiety and instinctual life Freud complements:

"Fortunately, the aggressive instincts are never alone, but always amalgamated to the erotic ones. These, the erotic instincts, have a lot to mitigate and much to remedy under the conditions of civilization that mankind has created" (FREUD, 1933/1996, p. 112).

In a complementary form and according to the understanding of Castiel (2007) with respect to the text of (1933[1932]1996), we can pursue some important implications of such considerations with respect to the economic problem of drives and sublimation. According to the author, Freud's theoretical development points to a central question with regard to the transformation of the drive field in cultural creation, which necessarily implies the process of sublimation. Metaphorically, says the author, we can consider through the deepening of Freud's theory at this moment that, what was before an issue concerning a matter of strength, of intensity, becomes something manageable through creation. So, for creation (in this psychoanalytic conception of subjectivity) to happen, it is necessary that the drive becomes energy (Eros). The concept of Eros permits, according to Castiel (2007), to imagine another understanding of Freud regarding sexuality. Articulating such ideas to the role of sublimation in the clinic the author emphasizes:

[...] Eros is the sexuality manifested through the accomplishments of a subject who can be sexual, are not satisfied directly through the sexual object, but can also be erotic manifestations. So, [...] the purpose of analysis would be precisely the creation of these new destinations to drive that make it possible to transform "the unstoppable of the sea into breeding ground", which undoubtedly brings us to destinations that the subject will give to the drive, in the sense of unique possibilities of creation. In this regard, the participation of sublimation in the clinic. (CASTIEL, 2007, p. 132).

In the author's point of view, this bias of understanding about life and death drivesarticulated to the question of sublimation, featuresa reliable understanding to the problems raised by Freud in texts such as "Analysis terminable and interminable" (1937/1996) and "An outline of Psychoanalysis" (1940/1996), where he would have 
encountered the powerfully insurmountable character of resistances motivated by such psychic forces and that counteract to those that would have been before, the only successful goals in an analysis.

So: "[...] the issue that is established for the analytic experience is how to build alternative paths so that the drive forces can take satisfaction in the psychic universe and in the field of alterity." (CASTIEL, 2007, p. 133).

Definitely the process of sublimation understood in this way does not presuppose more (as in the early Freudian articulations about the subject) a desexualization of the drives and the correlated symbolic impoverishment of subjectivity. On the contrary, now in this new perspective opened by Freud's latest writings, the process of sublimation is evidenced as a possible construction from the rest of the psychic that resists symbolization, the theoretical signaling of the importance of the management of helplessness in the face of the lack of the ultimate possibility of knowledge, where the transformation of death into life necessarily crosses invention and creation.

\section{SUBLIMATION FROM LACAN}

It is in the seminar "the ethics of psychoanalysis" ([1959-60]2008) that Lacan considers theoretically a rescue and deepening of Freud's issues mainly with relation to sublimation, here implying a reflective return to beyond the pleasure principle and/or to the death drive and to the lost object.

Surpassing the conservative views, in the various psychoanalytic understandings that tend to persist in associating sublimation to the social recognition/value of the object produced (which implies normativity), resuming the Freudian theory transmuted by the news of the second topical, Lacan tries to define sublimation in a strict way, emphasizing it as a psychic process which is only able to happen because the produced/created object is an object elevated to the dignity of the Thing. Sublimating, according to Lacan, is to elevate an object to the dignity of the Thing.

The author then rescues Freud's notion of "lost object" from reflections on the issues concerning the relations between subject and object. As we know, the search for the reunion with the lost object (das Ding) leads the subject to find other objects different from the original one, and according to Freud the lost object is lost forever: the result is that this reunion happens through an encounter with another object distinct from the primary one. The lost object is a Freudian notion that defines this as characterizing a mythical moment of the person's own psychic constitution, that moment in which lies the pathic record that some other time Freud (1930/1996) compares to an oceanic feeling. According to Lacan, the fact is that even though the originating object has never been lost, yet the 
sense of reunion retroactively indicates by the refound ${ }^{1}$ happening that something then may have been lost in a moment before the originating repression:

Such is the fundamental definition of the object, for Freud, in his directive function, which paradox has already been shown, because this object is not said to be really lost. The object is, by its nature, a refound object. That it has been lost is the consequence of that - butjust afterwards. And therefore it is refound, and the only way to know that it has been lost is through these reunions, through these refounds. We have refound here a fundamental structure, which allows us to articulate that the Thing in question is susceptible, in its structure, of being represented by what we have been calling for a long time, in respect to the discourse of boredom and prayer, of the Other thing. The Other thing, is essentially, the Thing. (LACAN, 1959-1960/2008, p. 145).

That is, the access to what could complete the subject reconstituting the "paradise lost" (alleged as existing from the impact of a reunion/refound) is barred, not for defense mechanisms, but because of the structural impossibility of the psyche. From this understanding we can only seize what the Thing is (this supposed object lost since ever) because of its character of absence. And although at the same time some reunions give it a status of real ${ }^{2}$, we can only define it as being the emptiness itself a feature of the psyche. In the most radical aspect of its psychic substantiality the Thing is the emptiness around which the psyche itself will be constituted. That's why the reunion with the Thing evidences, at best, a 'new' encounter with an Other given the impossibility of the symbolic grasp on its record the essence of the drive real. This other object, different from the original thing, will feature an object a to the subject, an object which is the cause of desire as the symbolic and imaginary support of its fantasy.

Being the Thing (das Ding) the emptiness inherent to the psyche itself, in that far-beyond of all possible symbolization, something that from the real suffers as signified, what is far beyond an articulation in language, in short, then the subject's search in refinding the lost object takes him necessarily toward what Freud (1920/1996) defined as the "beyond the pleasure principle". We are then taken to visualize that the very principle of pleasure is regulated by one further that pervades him and determines the last purpose of all drive requirement, that is, to reach the Thing, the full jouissance, the death.

\footnotetext{
1 "Fact of finding something that was lost and refinding something that one was separated from". - note on seminar 7 of J. Lacan.Fato

${ }^{2}$ Real - one of the psychic records according to J. Lacan. The real represents the drive field itself, the dispersive field disconnected from the symbolic and imaginary records, that which resists symbolization.
} 
From the conception of the unconscious structured like a language (Lacan, 1966/1998), we can understand the place of life as the organized set of representations, the structured symbolic (S2) where every possible form of knowledge construction lies. Life, as a bias drive is organized through the signifiers (representations) structured in symbolic and imaginary records, records of psychic representations where all forms of knowledge about the subject are organized. Death, in turn, substantiated by the partiality of the drive that resists symbolization, agitates the structured set of life, being itself something of the order of time, of the passage, of the future and of the movement, what breaks up with the symbolic organization given its character of far-beyond, of a stranger in the realm of the subject. Death while beyond the pleasure principle aims to the returning of what was prior to life, to the cessation of desire and to the ultimate completeness of the lack (Lacan, 1958/1999). The Thing itself represents death, and it is that something around which the subject will be constituted.

Finally, we can consider that the death drive destabilizes the characteristic order of the set organized by the tendency of the life drive, while its character of rupture with the pre-established, demands of the subject new implications in order to manage its most fundamental truth: the desire and the consequent lack of the object that could definitely cease incompleteness. So:

The drive is of death, because it is interfering with the organization established in life. It interferes in maintaining the homeostatic level of tension that guarantees the vital organization and increases this voltage. The elevation of tension will allow the inclusion, in the field of knowledge, of a new truth from the drive. If the drive comes to deal with this knowledge that is life, it must then be the death drive. This is the cause of intervention $\mathrm{S} 1$ makes in $\mathrm{S} 2$ and that results in the emergence of the subject. S1 will require $\mathrm{S} 2$ to a new organization of knowledge to include the new master signifier that represents the subject. (WINE, 1992, p. 154).

In other words, in order that subjectivity can be restructured from the irruption of the real (S1), it is necessary that the advent of the psychic ${ }^{3}$ subject occurs, that is, that from the pathomenon cause (Lacan, 1962-63/2005) there is a signified creation, or the formation of new mental representations, in order that to the psyche a destination is made possible to the excess of the drive. It becomes clear to us here the understanding that the advent of the psychic subject refers to a movement of subjectivity, which implies creation and that features, by a unique destina-

3 "Contradictory to this existing world of the order of being, the subject is an event, a movement or an act of becoming, and of the non-existence. The effect that lasts and registers the emergence of the subject is his production, inscription of a new signified". (WINE, N., 1992, p. 138) 
tion (particular), the process of sublimation itself. And it is through this bias that Wine (1992) understands the process of sublimation as being particularly responsible for the advent of the psychic subject par excellence.

Retaking then Lacan's phrase, an object elevated to the dignity of the Thing is an object that can be an object, but never any object, so for this object to be elevated to that dignity, the emptiness around which the signifiers (their symbolic constitution) surround will be the core revealed covertly, only possible from a transcendence with respect to the characteristics of the used object itself, to the extent that this reveals an Other thing when trying to represent the Thing itself. So, the Lacanian understanding about sublimation allows us to characterize this process as the possibility of the advent of the subject (since it outlines for destinations other than the ego defense mechanisms) fundamentally from the creative processes, to the extent that something is created from nothing, from the emptiness of the Thing:

"I settle this - an object can fulfill this function that allows it not to avoid the Thing as signified, but to represent it to the extent that this object is created" (LACAN, 1959-60/2008, p. 146).

As a characteristic fact of all sublimation, the created object watches over the Thing in so far as it constitutes a possible representation of this emptiness, however, it ends up also for revealing the mark of das Ding to the extent that this emptiness is impossible to cover completely. So, with this in mind, we will understand that every form of art, as well as other human productions, will be characterized by its creator aspect, in the creative sense that will shape and give life to what doesn't have a pre-determined definition. From the point of view of the psyche structure, we can then determine that such creative processes will reposition the subject in relation to what eludes him, so that the process of creating ends up by featuring a moment of special subjectivation if compared to the advent of the subject of the unconscious. So, in addition to the material object, the produced artifact itself and its particular substantiality, the fact is that to the creator subject internal transformations will occur since such creation happens through a sublimating way:

"The works of sublimation, more than material things, are images and signified ways created again." (NASIO, 1995, p. 89).

In short, we are referring here to a restructuring of the symbolic field triggered by the search for satisfaction that the beyond the pleasure principle imposes on the psyche. So, elevating an object to the dignity of the Thing corresponds to transcending in a certain sense the characteristics that define any object a priori, any mundane substantiality, lifting it to a status of signified which is able to represent an Other thing: 
When you elevate an existing object to the dignity of the Thing that does not exist, the psychic energy does not discharge in the object. Retained in the apparatus, it structures and enlarges its networks. [...] From the encounter of this emptiness, which is the real for man, a symbolic response will happen, always differentiated in the process of repetition. The more the subject is free of the chains and of the signified that are already there on his network, the more differentiated is his production. He will produce in the place in which repetition appears as a difference, where the reunion with the Thing is in fact a reunion with something, an emptiness. The subject designates, then, another object that, when deployed, is revealed to be the progress of this subject who advances, failure after failure, in an attempt to achieve the Thing. (WINE, 1992, p. 145).

That is, although the process of sublimation is characterized, eventually, as a symbolic-imaginary production, with different failures in what concerns the surroundings from the emptiness that could ensure it full representation, the fact is that the creative process provides a magnification of the psyche itself in so far as it expands its network of articulated representations. In short, it's for the vicissitude of the path of sublimation that the psyche expands and produces possible ways of jouissance.

At this point, as Wine (1992) highlights in the above passage, it is prudent to also emphasize the peculiarities of the question on drive satisfaction which is present in sublimation. As well highlighted, the psychic energy does not end on the produced object, so that if that were the case we could understand the process of sublimation as fundamentally cathartic. It is true that there will be productions in which there is also the phenomenon of catharsis, no doubt, but the essential question concerning sublimating satisfaction revolves around the production while signified. So, the partial satisfaction obtained through a sublimating way, concerns a jouissance coming from the production of a new psychic representation, to the extent that "the signified is the cause of jouissance" (WINE, 1992, p. 161). We can then consider that with a production through the way of sublimation, the subject goes round the emptiness of the Thing, producing something from this, from where he will constitute a possible destination possible to the drive, which will cause him a partial satisfaction, sometimes also a catharsis, but primarily a movement of subjectivation that extends the symbolic richness of his own psychic structure. The subject caused and put in motion by the excess of the drive turns out to not reaching the Thing (das Ding), however, from its outline in relation to emptiness there lies the subjective effectiveness of the sublimating course: 
"Each failure from exhausting the drive energy in a satisfactory object is part of a new signified trait, i.e. part of that energy returns to the self as an identifying "memory" of the course." (WINE, 1992, p. 138).

\section{THE LIMITS OF AN ANALYSIS, THE SUBLIMATION AND THE CREATIVE PROCESSES}

Finally, up to this point of our reflection, we can understand sublimation as a psychic process inextricably coupled to creative potentiality, and because of this, it characterizes modes of subjectivation which are unique to each subject, ultimately implying other possibilities for the conditions of psychic "discontent" (return of the repressed).

In what concerns the consequences of an analytical process, considering the limits postulated by Freud, especially the "repetition compulsion", we would question: would the psychoanalytic interpretation be presented as a reductionist method of grasping subjectivity from a specific moment in the course of an analysis? And, considering an analytical process as a whole, will the interpretive method, in any moment, be characterized as a narrowing of the drive field to the extent that it produces the 'endless' chain of meanings to other meanings? (though it concerns the sliding of the signifiers).

By way of conclusion and final clearings we should consider that Lacan (1964/1988) in his seminar on the four fundamental concepts of psychoanalysis, articulates his notion of "tiqué" as being a modality of differential repetition. The author explains that the repetition has two aspects, one on the order of a symbolic automatism (the return and the insistence of certain signifiers in the chain of discourse), and on the other hand, the dimension of the real of repetition ("tiqué"). The differential repetition concerns the essence of the very act of repeating, which ultimately implies in understanding the real of this repetition as something that appears as a precondition to constitute (pure possibility) something else of the order of the new (creative processes). According to Torezan (2012, p. 119-120): "The differential repetition of the order of the Real, tiqué, is never a mere reproduction. On the contrary, it is a movement in the direction of the impossible search of das Ding, a fact that refers to the concept of sublimation as a producer of the elevation of the object to the Thing".

We could think that a psychoanalytic clinic that steps for analytical courses that emphasize creations by the subject is directly complementary to a clinic of the interpretation, the elaboration of meanings. Moreover, recalling the limits of an analysis identified by Freud, as well as Lacan's (1964/1988; 1975-76/2007) advances of towards a clinic of the real, we would have from such understandings about sublimation a useful clinical targeting in order to proceed with the subject 
beyond the known and the forgotten (repression), so that we could formulate that where the meaning is missing, there should be invention/creation.

We intend to, with respect to psychoanalytic praxis, to point out the following: within the limits of an analysis where the meaning is missing, in short, not because of the work of repression, but because of the structural impossibility of access to the full Truth, there must be another way of constructing the meaning to the subject. This form of subjectivation, for beyond the insights arising from psychic elaboration in its contact with what repressed (that chose not to know) would point to another possible way of knowing about yourself. We emphasize here then not the forgotten knowledge that is (repression/castration) accessible by the interpretive method, but that knowledge that is impossible to know. Of this there's nothing to rescue and/or recover, given that in its place there is nothing, unless the Thing (das Ding), leaving to the subject from there to create/invent meanings and possibilities.

Recebido/Received: 3/10/2014. Aprovado/Accepted: 18/4/2015.

\section{REFERENCES}

BIRMAN, J. (2002) "Fantasiando sobre a sublime ação". In BARTUCCI,

G. (ORG). Psicanálise, arte e estéticas de subjetivação. Rio de Janeiro: Imago. CASTIEL, S. V. (2007) Sublimação: clínica e metapsicologia. São Paulo: Escuta. FREUD, S. (1996) Obras psicológicas Completas. Rio de Janeiro: Imago.

(1908) "Moral sexual "civilizada" e doença nervosa moderna", Vol. IX, p. $165-186$

(1910) "Leonardo da Vinci e uma lembrança de sua infância", Vol. XI, p. 67-141.

(1914) "Sobre o narcisismo: Uma introdução", Vol. XIV, p. 81-108.

(1915) "Os instintos e suas vicissitudes", Vol. XIV, p. 123-144.

(1920) "Além do princípio do prazer", Vol. XVIII, p. 17-75.

(1923) "O ego e o id", Vol. XIX, p. 25-80.

(1930[1929]) "O mal-estar na civilização", Vol. XXI, p. 73-148.

(1933 [1932]) "Novas conferências introdutórias sobre psicanálise", Vol. XXII, p. 85-112.

(1937) "Análise terminável e interminável”, Vol. XXIII, p. 231-270.

(1940 [1938]) “Algumas lições elementares de Psicanálise", Vol. XXIII, p. 301-306. 
LACAN, J. (1958 [1957]/1999) O seminário, livro 5: As formações do inconsciente. Rio de Janeiro: Jorge Zahar Ed. (1959-60/2008) O seminário, livro 7: A ética da psicanálise. Rio de Janeiro: Jorge Zahar Ed.

(1962-63/2005) O seminário, livro 10: A angústia. Rio de Janeiro: Jorge Zahar Ed.

. (1964/1988). O seminário, livro 11: os quatro conceitos fundamentais da psicanálise. Rio de Janeiro: Jorge Zahar Ed. . (1966/1998) Escritos. Rio de Janeiro: Jorge Zahar Ed. . (1975-76/2007). O seminário, livro 23: O Sinthoma. Rio de Janeiro: Jorge Zahar Ed.

LAPLANCHE, J.; PONTALIS, J. B. (2001) Vocabulário da psicanálise. São Paulo: Martins Fontes.

NASIO, J-D. (1995) Lições sobre os sete conceitos cruciais da psicanálise. Rio de Janeiro: Jorge Zahar Ed.

RINALDI, D. (1996) A Ética da diferença. Rio de Janeiro: EdUERJ: Jorge Zahar.

TOREZAN, Z. C. F. (2012) Sublimação, ato criativo e sujeito na psicanálise. Londrina: Eduel.

WINE, N. (1992) Pulsão e inconsciente: a sublimação e o advento do sujeito. Rio de Janeiro: Jorge Zahar.

Leandro Anselmo Todesqui Tavares

leandro_anselmo@hotmail.com

Francisco Hashimoto

frahas@uol.com.br

Traduzido do português por Doris Dana/ translated from portuguese by Doris Dana

dorisdana@uol.com.br 